University of Wisconsin Milwaukee

UWM Digital Commons

\title{
Characteristics of Deforestation in the Democratic People's Republic of Korea (North Korea) between the 1980s and 2000s
}

\author{
Woonsup Choi \\ University of Wisconsin-Milwaukee, choiw@uwm.edu \\ Sangjun Kang \\ kangsangjun@gmail.com \\ Jinmu Choi \\ cjm89@khu.ac.kr \\ Joseph James Larsen \\ University of Wisconsin-Milwaukee, larsen3@uwm.edu \\ Chungweon Oh \\ University of West Georgia \& Namseoul University, ohrora@nsu.ac.kr
}

Follow this and additional works at: https://dc.uwm.edu/geog_facart

Part of the Geography Commons

\section{Recommended Citation}

Choi, W., S. Kang, J. Choi, J.J. Larsen, C. Oh, and Y. Na, "Characteristics of Deforestation in the Democratic People's Republic of Korea (North Korea) between the 1980s and 2000s," Regional Environmental Change, DOI: 10.1007/s10113-016-1022-3, vol. 17, no. 2, pp. 379-388, 2017

This Article is brought to you for free and open access by UWM Digital Commons. It has been accepted for inclusion in Geography Faculty Articles by an authorized administrator of UWM Digital Commons. For more information, please contact open-access@uwm.edu. 


\title{
Characteristics of Deforestation in the Democratic People's Republic of Korea
}

(North Korea) between the 1980s and 2000s

\author{
Choi, Woonsup \\ Dept. of Geography, Kyung Hee University and University of Wisconsin-Milwaukee \\ choiw@uwm.edu \\ Dongdaemun-gu, Seoul, Republic of Korea \\ Kang, Sangjun \\ Dept. of Regional Development, Gangneung-Wonju National University \\ kangsangjun@gmail.com \\ Gangneung-si, Gangwon-do, Republic of Korea
}

Choi, Jinmu (corresponding author)

Dept. of Geography, Kyung Hee University.

cjm89@khu.ac.kr

Dongdaemun-gu, Seoul, Republic of Korea
Larsen, Joseph James
Dept. of Geography, University of Wisconsin-Milwaukee, larsen3@uwm.edu Milwaukee, Wisconsin, United States

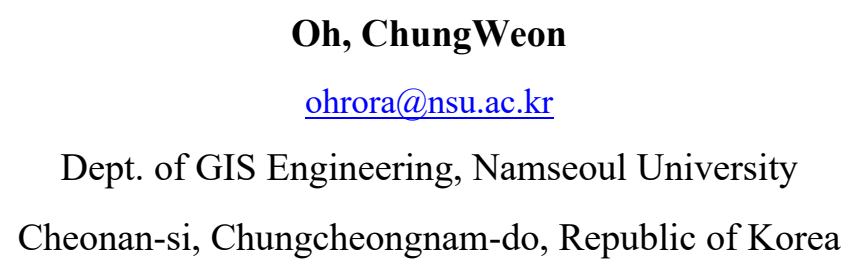


34 There has been a significant lack of land cover change studies in relation to deforestation in the

35 Democratic People's Republic of Korea (North Korea). The purpose of this study is to 36 characterise deforestation in North Korea through land cover change trajectory and spatial 37 analysis. We used three $30 \mathrm{-m}$ gridded land cover data sets for North Korea representing the 38 conditions of the late 1980s, 1990s, and 2000s, respectively, as well as a digital elevation model. 39 We examined the land cover trajectories during the two decades, i.e. which land cover became 40 which at the pixel level. In addition, we calculated topographic characteristics of deforested pixels. 41 Major findings from the study are summarised as follows: (1) net forest loss in North Korea 42 slowed since the 1990s, whereas land cover changes were active; (2) as a result of deforestation, 43 forest land cover became mostly agricultural and grassland; (3) expansion of agricultural land 44 cover continued during the time; and (4) elevation and slope of deforested areas decreased slightly 45 in the latter decade. The key contribution of the study is that it has demonstrated which land cover 46 became which at the $30-\mathrm{m}$ pixel level, complementing existing studies that examined overall 47 forest stock in North Korea.

Keywords: Deforestation; North Korea; Forest; Land Cover; Spatial Distribution 50 
Land use/cover change results in significant consequences in the environment, in terms of climate (e.g. Findell et al. 2007), hydrology (e.g. Sajikumar \& Remya 2015), and ecology (e.g. Parton et al. 2005), among others. Deforestation, which implies the long-term or permanent loss of forest cover and its transformation into another land cover, is one of the most widespread issues of land cover change. During the period 1990-2010, Africa and South America lost millions of hectare of forest per decade respectively, particularly in Brazil and Nigeria, by far exceeding other continents (FAO, 2010). Naturally, deforestation taking place in the Amazon or the tropics in general tends to have received most of the attention in recent decades, but deforestation is also of great concern in Asia, the most populous continent in the world (Zhao et al, 2006). This study presents results from an analysis of deforestation in the Democratic People's Republic of Korea (also known as North Korea).

Deforestation in general has many direct and indirect causes. The overwhelming direct cause of deforestation is agriculture. Deforestation from subsistence and commercial farming is totaling about $70 \%$ of the total deforestation according to the United Nations Framework Convention on Climate Change (UNFCCC, 2007). The majority of studies of deforestation point out the expansion of agricultural practices as the major global cause (Debolini et al, 2013). Geist \& Lambin (2002) found that agricultural expansion was by far the leading land use changes associated with nearly all tropical deforestation case. Demand for land for grazing is another important driving factor of deforestation in Latin America and Africa (FAO, 2012). Agricultural expansion and timber harvest were primary causes of large-scale deforestation in Asia (Zhao et al., 2006).

Forest cover declined in Asia between 1990 and 2000 but increased later (FAO, 2010). There is also substantial regional variability in the forest cover change in Asia. For example, China's afforestation efforts greatly contributed to the forest cover increase after 2000, but South and Southeast Asian countries continued to lose net forest at high rates (FAO, 2010). Forest cover continued to decrease in North Korea (Engler et al, 2014). Deforestation accelerated in North Korea during the 1990s compared to the preceding decade not only in terms of quantity but also in shape (Kang \& Choi, 2014). Deforestation in North Korea in recent decades has been receiving 
attention due to its relationship with the famine and floods its people suffered. Between 1995 and 1996, several floods damaged much of the land used for agriculture. It was estimated that 1.3 million hectares of agricultural land was damaged and lost due to inundation and sedimentation (IUFRO, 2007). The debris left afterward in lower elevation zones made the land unusable for growing crops (Kim \& Chi, 1998). This is a partial cause of the famine that occurred in North Korea in the 1990s, resulting in more clear-cutting of forest to expand the agricultural land (IUFRO, 2007).

Since North Korea is one of the few closed countries left in the world, literature related to land cover change in North Korea are quite sparse and even fewer peer-reviewed studies exist in specific relation to deforestation in North Korea. Since the Korean War, there had been virtually no reliable information regarding the size and condition of forests in the country until recently (Lee \& Kim, 2000). The aforementioned studies provide recent pictures of deforestation in North Korea using remotely sensed data. What we find missing in the literature is an analysis of what land covers deforestation resulted in and what land covers converted to forest. We also paid attention to the locational characteristics of deforestation. For example, is deforestation occurring in higher and higher elevation? Where did forest become agricultural land and where did grassland become forest? Topography and accessibility of people to forest are known to affect deforestation rates (Vagen 2006). In short, the purpose of this study is to characterise deforestation in North Korea through land cover change trajectory and spatial analysis. Specifically, this study attempts to 1) identify areas where deforestation has taken place recently, 2) measure at what slope and elevation the deforestation has occurred, and 3) analyse land cover changes between forest and other land covers.

\section{MATERIALS AND METHODS}

The data used for this study consists of three gridded land cover data sets of North Korea, each of which represents land cover conditions in the late 1980s, 1990s, and 2000s respectively. Hereafter they are referred to as the 1980, 1990, and 2000 data sets. Land cover data as digital maps were produced by the Republic of Korea (South Korea)'s Ministry of Environment (MoE) (MoE, 2016b). The 1980 and 1990 data sets were produced from the Landsat TM imagery for 1987-1989 and 1997-1999 respectively. The 2000 data set was produced from the Landsat 7 ETM+ imagery for 2008-2010 (MoE, 2016a). Each land cover digital map covers $15^{\prime} \times 15^{\prime}$ at the 
1:50 000 scale so that 487 maps were produced to cover the entire North Korea for each term.

For the accuracy assessment, MoE derived samples from the center of the 1 minute grids of each 1:50,000 digital map $\left(15^{\prime} \times 15^{\prime}\right)$ so that 225 samples were checked for each map. As reference data, topographic maps for North Korea (1:50 000), military base maps (1:50 000) by the Republic of Korea Army Mapping Agency, forest type maps, and vegetation maps were used. According to the land cover map guideline by MoE (2013), the land cover data had more than $70 \%$ accuracy for classification in the North Korean region. The land cover maps have seven land cover classes: Water, Developed, Barren Land, Grassland, Wetland, Forest, and Agriculture (upper cases were used in this document to represent land cover classes from the data sets). The meaning of each class is presented in Table 1. Fig. 1 shows that Forest is the predominant land cover, located mostly in eastern and northern parts of the country. Agricultural lands are concentrated in western and coastal regions.

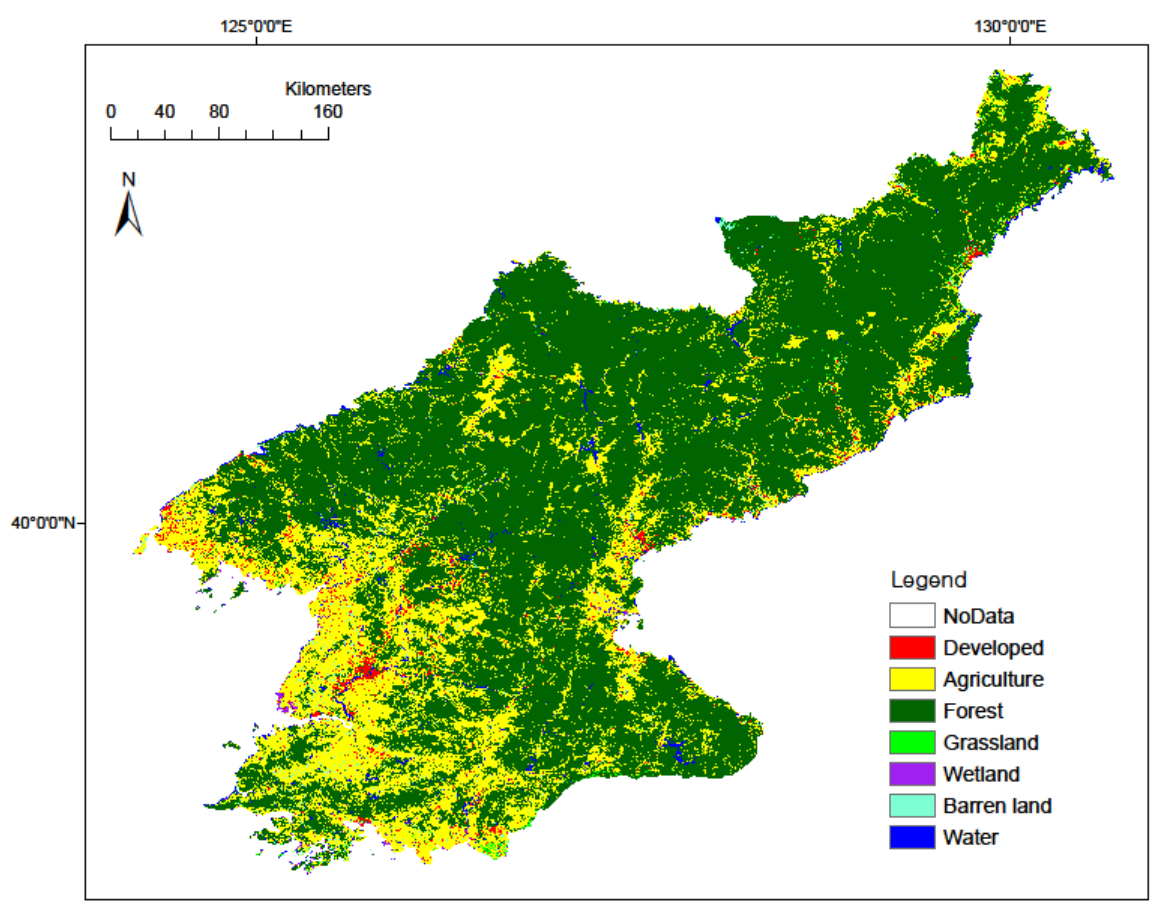

Fig. 1 Land cover of North Korea from the 2000 data set

Land cover changes over time at each pixel were analyzed using a change trajectory approach on ArcGIS $10^{\circledR}$. Here the trajectory approach specifically means identifying the succession of land cover over time at a particular location, as was conducted for gridded land 
cover data sets by Feng \& Liu (2014) and Wang et al. (2013). In the studies, the final resulting grids have cell values that indicate the land cover at each time represented by each input grid. In this study, it was implemented according to the following steps. First, for the most recent land cover data set (the 2000 data set), each land cover class was assigned a number from 1 to 7 as pixel attributes (Table 1). Second, for the 1990 data set, each land cover class was assigned a number from 10 to 70 , with 10 corresponding to 1 and 70 to 7 in the 2000 data set respectively. Third, in the same way, each land cover class in the 1980 data set was assigned a number from 100 to 700 . Fourth, all three layers were overlaid and corresponding pixel values were added. The final three digit pixel values indicate the land cover change trajectory at the pixel. For example, a pixel value 342 means that the pixel was Forest in the 1980s, became Grassland in the 1990s, and then Agriculture in the 2000s. Two or three consecutive identical codes indicate no changes during the time spans. We acknowledge the land cover classification error, thus the results must be interpreted with caution. We generally neglect changes that occurred to small extents.

Table 1. Land cover codes used for change trajectory analysis

\begin{tabular}{|l|l|l|l|}
\hline Land cover class (notes from MoE (2013)) & 1980 & 1990 & 2000 \\
\hline $\begin{array}{l}\text { Developed (includes built-up areas such as residential, commercial, } \\
\text { industrial, transportation) }\end{array}$ & 100 & 10 & 1 \\
\hline Agriculture (includes crop fields, orchards, and dairy farms) & 200 & 20 & 2 \\
\hline Forest (land where trees and shrubs grow collectively) & 300 & 30 & 3 \\
\hline $\begin{array}{l}\text { Grassland (land covered by herbaceous plants, including both natural and } \\
\text { man-made grasslands) }\end{array}$ & 400 & 40 & 4 \\
\hline Wetland (land that remains naturally saturated with water) & 500 & 50 & 5 \\
\hline Barren land (bare ground without vegetation) & 600 & 60 & 6 \\
\hline Water (includes lakes, reservoirs, and swamps) & 700 & 70 & 7 \\
\hline
\end{tabular}
areas. DEM data were downloaded from ASTER global DEM (GDEM) Web site (NASA, 2012). 
The spatial resolution of GDEM data is $30 \mathrm{~m}$. The data sets were projected to a Universal Transverse Mercator (UTM) projection, JGD 2000 UTM Zone 52N (North Korea). Slope values were then calculated from the DEM.

The deforested areas were derived by partially implementing the change trajectory approach. For deforestation between the 1980s and 1990s (1980s-1990s), two grid layers were overlaid to add the values as in Table 1. Then only the pixels that were Forest in the 1980s and became something else in the 1990s were extracted and reclassified to the pixel value of 1 . Deforestation between the 1990s and 2000s (1990s-2000s) was derived in the same manner. This data were used to calculate the elevation and slope of the deforested areas, taking the product of the DEM and slope layers with each of the reclassified deforestation grids.

\section{RESULTS AND DISCUSSION}

\section{Magnitude of deforestation and other land cover change}

The results show a significant decrease in Forest between the 1980s and 1990s (Table 2). The decrease is only $6 \%$, but the areal extent is more than $5000 \mathrm{~km}^{2}$. During the same period, Developed increased by 44\%, Agriculture 12\%, and Grassland 24\%. Agriculture increased by more than $2600 \mathrm{~km}^{2}$, which is more than half the size of deforestation. Between the 1990s and 2000 s, Forest barely changed in its areal extent, but Agriculture increased by $27 \%$ and Grassland decreased by $91 \%$. It is interesting to note that Developed decreased by $5 \%$ during the 1990 s2000s. We speculate that it could be partly due to classification error but also conversion of abandoned built-up lands to other land covers. There are some conflicting reports regarding forest cover change in North Korea in the 2000s. Kang and Choi (2014) reported a large forest cover decrease between the 1990s and 2000s from 100-m-resolution land cover data sets, but Engler et al. (2014) reported little change in per-pixel tree cover percentage between the early and late 2000s from MODIS (moderate-resolution imaging spectroradiometer) data. The per-pixel tree cover percentage decreased a lot between the early 1990s and the early 2000s (Engler et al. 2014).

Table 2. Areal extent (in $\mathbf{k m}^{2}$ ) of each land cover class calculated based on the number of pixels and the spatial resolution of the land cover datasets. Numbers in parentheses are percent changes from the previous dataset.

\begin{tabular}{|c|c|c|c|}
\hline Data set & 1980 & 1990 & 2000 \\
\hline
\end{tabular}




\begin{tabular}{|c|c|c|c|}
\hline Developed & 1405 & $\begin{array}{l}2030 \\
(44 \%)\end{array}$ & $\begin{array}{l}1933 \\
(-5 \%)\end{array}$ \\
\hline Agriculture & 21318 & $\begin{array}{l}23965 \\
(12 \%)\end{array}$ & $\begin{array}{r}30344 \\
(27 \%)\end{array}$ \\
\hline Forest & 91874 & $\begin{array}{r}86565 \\
(-6 \%)\end{array}$ & $\begin{array}{r}86428 \\
(0 \%)\end{array}$ \\
\hline Grassland & 5027 & $\begin{array}{l}6238 \\
(24 \%)\end{array}$ & $\begin{array}{r}543 \\
(-91 \%)\end{array}$ \\
\hline Wetland & 447 & $\begin{array}{r}359 \\
(-20 \%)\end{array}$ & $\begin{array}{r}275 \\
(-23 \%)\end{array}$ \\
\hline Barren land & 983 & $\begin{array}{l}1826 \\
(86 \%)\end{array}$ & $\begin{array}{r}1207 \\
(-34 \%)\end{array}$ \\
\hline Water & 1497 & $\begin{array}{l}1546 \\
(3 \%)\end{array}$ & $\begin{array}{l}1826 \\
(18 \%)\end{array}$ \\
\hline
\end{tabular}

Fig. 2 portrays the extent of deforested areas for each of the two decades overlaid by provincial boundaries. The upper panel shows the pixels that was Forest in the 1980 data and became something else in the 1990 data. The lower panel shows the pixels that was Forest in the 1990 data (regardless of whether they were Forest or something else in the 1980 data) and became something else in the 2000 data. Between the 1980s and 1990s, deforestation occurred in much of the country. On the other hand, deforestation during the 1990s-2000s appears to have concentrated in western provinces ( $s i$ and $d o$ ) such as Jagang-do, Pyeonganbuk-do, Pyeongannam-do and Pyeongyang-si. Pyeongyang (also known as Pyongyang) is the capital of and the largest city province in the country and deforestation is quite visible in and outside of Pyeongyang between the 1990s and 2000s. Jagang-do is a very remote and mountainous province, and deforestation was quite intensive in the middle of the province during the period. In both decades, deforestation was fairly widespread across the country, except in very inland areas (e.g. Yanggang-do) which are mostly high mountains and plateaus. 

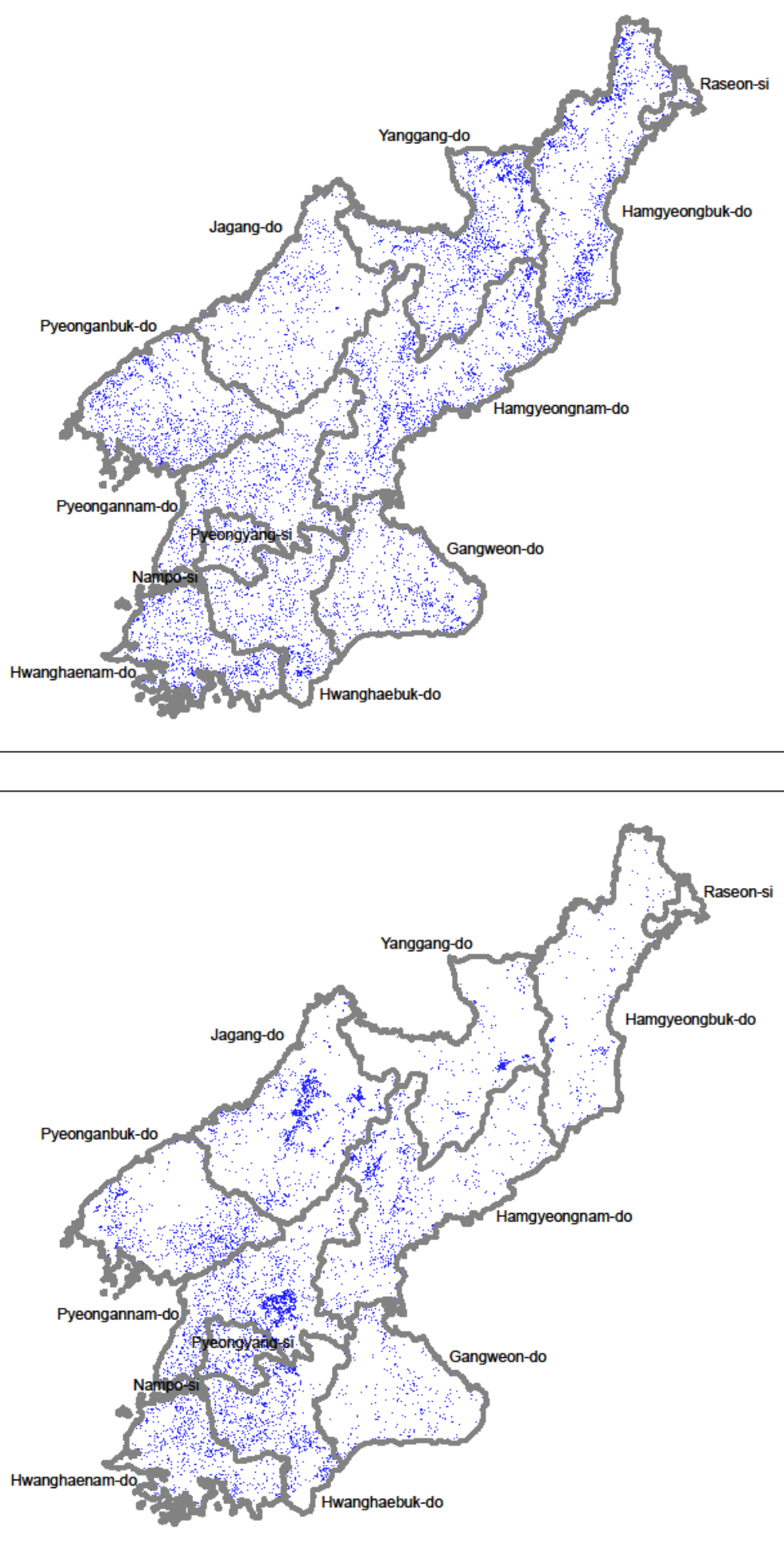

Fig. 2 Areas where deforestation occurred during the 1980s-1990s (upper panel) and the 
195

196

197

198

199

200

201

202

203

204

205

206

207

208

209

210

211

212

213

Table 3. Grain production and gross domestic product (GDP) growth rate during the 1990s in North Korea (Lee, 2008)

\begin{tabular}{|c|c|c|c|c|c|c|c|c|c|c|}
\hline Year & 1991 & 1992 & 1993 & 1994 & 1995 & 1996 & 1997 & 1998 & 1999 & 2000 \\
\hline $\begin{array}{c}\text { Grain Production } \\
\text { (ton) }\end{array}$ & 443 & 427 & 388 & 413 & 345 & 369 & 349 & 389 & 422 & 359 \\
\hline $\begin{array}{c}\text { GDP Growth } \\
\text { Rate (\%) }\end{array}$ & -3.5 & -6.0 & -4.2 & -2.1 & -4.1 & -3.6 & -6.3 & -1.1 & 6.2 & 1.3 \\
\hline
\end{tabular}

214

215

216

217

218

219

This rapid decrease in Forest during the 1980s-2000s is alarming but not surprising, given the literature which stated increasing dependence on these resources due to natural disasters and flooding (UNEP, 2003; Myeong \& Hong, 2009). The significant increase in Agriculture also closely agrees with these works, which noted the natural disasters that caused destruction of previous agricultural land and more clear-cutting of forests, as well as food shortages in the country.

Economically, North Korea continued a negative economic growth since 1991 and the total food supply was reduced (Table 3). It caused a lot of people to starve to death since the mid1990s (Kim, 2009). Since 1994, food imports to North Korea were also rapidly reduced for two reasons. Domestically there was a lack of foreign currency due to economic deterioration and the lack of substitute exports. Internationally, China reduced the grain exports from northeastern China in the mid-1990s because of the food shortage caused by flooding in southern China (Kim $\&$ Park, 1995). In addition, when droughts and floods ruined harvests in the 1990s, a famine was touched off and claimed numerous lives. Villagers desperately scoured forests for food and fuel (Stone, 2012).

in North Korea (Lee, 2008)

\section{Land cover change trajectories regarding forest}

The entire land cover change matrices are presented in Tables 4 and 5. Table 4 shows how each of the seven land cover classes in the 1980s (rows) changed by the 1990s (columns) both in terms area $\left(\mathrm{km}^{2}\right)$ and percentage. Pixels of Agriculture remained mostly Agriculture $(66.1 \%)$ and $17 \%$ of it became Forest and 12\% became Grassland by the 1990 s. Forest did not 
change much in terms of percentage, with $87.9 \%$ of Forest pixels remaining Forest and $7.2 \%$ of

221 it becoming Agriculture in the 1990s. However, the absolute size of the Forest-to-Agriculture conversion is quite large $\left(6602 \mathrm{~km}^{2}\right)$, almost half that of Agriculture-to-Agriculture and larger than any other entry in the table. It is also much larger than the Agriculture-to-Forest conversion

$224\left(3630 \mathrm{~km}^{2}\right)$. We also note that the Grassland-to-Agriculture conversion $\left(2172 \mathrm{~km}^{2}\right)$ is much

225 larger than the Agriculture-to-Grassland conversion $\left(1541 \mathrm{~km}^{2}\right)$.

226 Table 4. Land cover change matrix between the 1980 and 1990 data sets. Integer entries are the area (in $\mathbf{~ k m}^{2}$ ) of corresponding changes and percentage entries are with respect to the sum on each row. Rows are for the 1980 data and columns are the 1990 data. For example, $87.9 \%$ of Forest $(80$ $\left.741 \mathrm{~km}^{2}\right)$ in the 1980 data remained Forest in the 1990 data while $7.2 \%\left(6602 \mathrm{~km}^{2}\right)$ of it became Agriculture.

\begin{tabular}{|c|c|c|c|c|c|c|c|c|}
\hline 1990 data & Developed & Agriculture & Forest & Grassland & Wetland & $\begin{array}{l}\text { Barren } \\
\text { land }\end{array}$ & Water & Sum \\
\hline \multirow[t]{2}{*}{ Developed } & 741 & 387 & 106 & 88 & 13 & 47 & 20 & 1403 \\
\hline & $52.8 \%$ & $27.6 \%$ & $7.6 \%$ & $6.3 \%$ & $0.9 \%$ & $3.3 \%$ & $1.4 \%$ & $100 \%$ \\
\hline \multirow[t]{2}{*}{ Agriculture } & 859 & 14093 & 3630 & 1541 & 46 & 968 & 168 & 21305 \\
\hline & $4.0 \%$ & $66.1 \%$ & $17.0 \%$ & $7.2 \%$ & $0.2 \%$ & $4.5 \%$ & $0.8 \%$ & $100 \%$ \\
\hline \multirow[t]{2}{*}{ Forest } & 246 & 6602 & 80741 & 3771 & 26 & 369 & 107 & 91861 \\
\hline & $0.3 \%$ & $7.2 \%$ & $87.9 \%$ & $4.1 \%$ & $0.0 \%$ & $0.4 \%$ & $0.1 \%$ & $100 \%$ \\
\hline \multirow[t]{2}{*}{ Grassland } & 91 & 2172 & 1864 & 692 & 10 & 166 & 29 & 5025 \\
\hline & $1.8 \%$ & $43.2 \%$ & $37.1 \%$ & $13.8 \%$ & $0.2 \%$ & $3.3 \%$ & $0.6 \%$ & $100 \%$ \\
\hline \multirow[t]{2}{*}{ Wetland } & 24 & 106 & 29 & 22 & 186 & 21 & 56 & 445 \\
\hline & $5.5 \%$ & $23.8 \%$ & $6.6 \%$ & $4.9 \%$ & $41.9 \%$ & $4.7 \%$ & $12.7 \%$ & $100 \%$ \\
\hline \multirow[t]{2}{*}{$\begin{array}{l}\text { Barren } \\
\text { land }\end{array}$} & 41 & 478 & 119 & 80 & 7 & 205 & 51 & 980 \\
\hline & $4.2 \%$ & $48.7 \%$ & $12.2 \%$ & $8.1 \%$ & $0.7 \%$ & $20.9 \%$ & $5.2 \%$ & $100 \%$ \\
\hline \multirow[t]{2}{*}{ Water } & 27 & 123 & 69 & 43 & 69 & 48 & 1,109 & 1489 \\
\hline & $1.8 \%$ & $8.2 \%$ & $4.6 \%$ & $2.9 \%$ & $4.7 \%$ & $3.3 \%$ & $74.5 \%$ & $100 \%$ \\
\hline
\end{tabular}


Table 5 is the change matrix between the 1990s and 2000s. The Forest-to-Agriculture conversion took place over an area of $7196 \mathrm{~km}^{2}$, increasing by $9 \%$ of the same change between the 1980s and 1990s. It is worth noting that conversion to Forest occurred to a large extent as well. The Agriculture-to-Forest conversion occurred over an area of $3462 \mathrm{~km}^{2}$ and the Grassland-toForest conversion over $3575 \mathrm{~km}^{2}$. The Grassland-to-Agriculture and Forest-to-Agriculture conversions occurred a lot as well, over areas of $2205 \mathrm{~km}^{2}$ and $7196 \mathrm{~km}^{2}$, respectively. Examination of the maps reveals that the Agriculture-to-Forest conversion spreads out across the country, but the Grassland-to-Forest conversion particularly concentrates in Yanggang-do, one of the most remote and densely forested areas.

Table 5. Same as Table 4 but for the 1990 and 2000 data sets

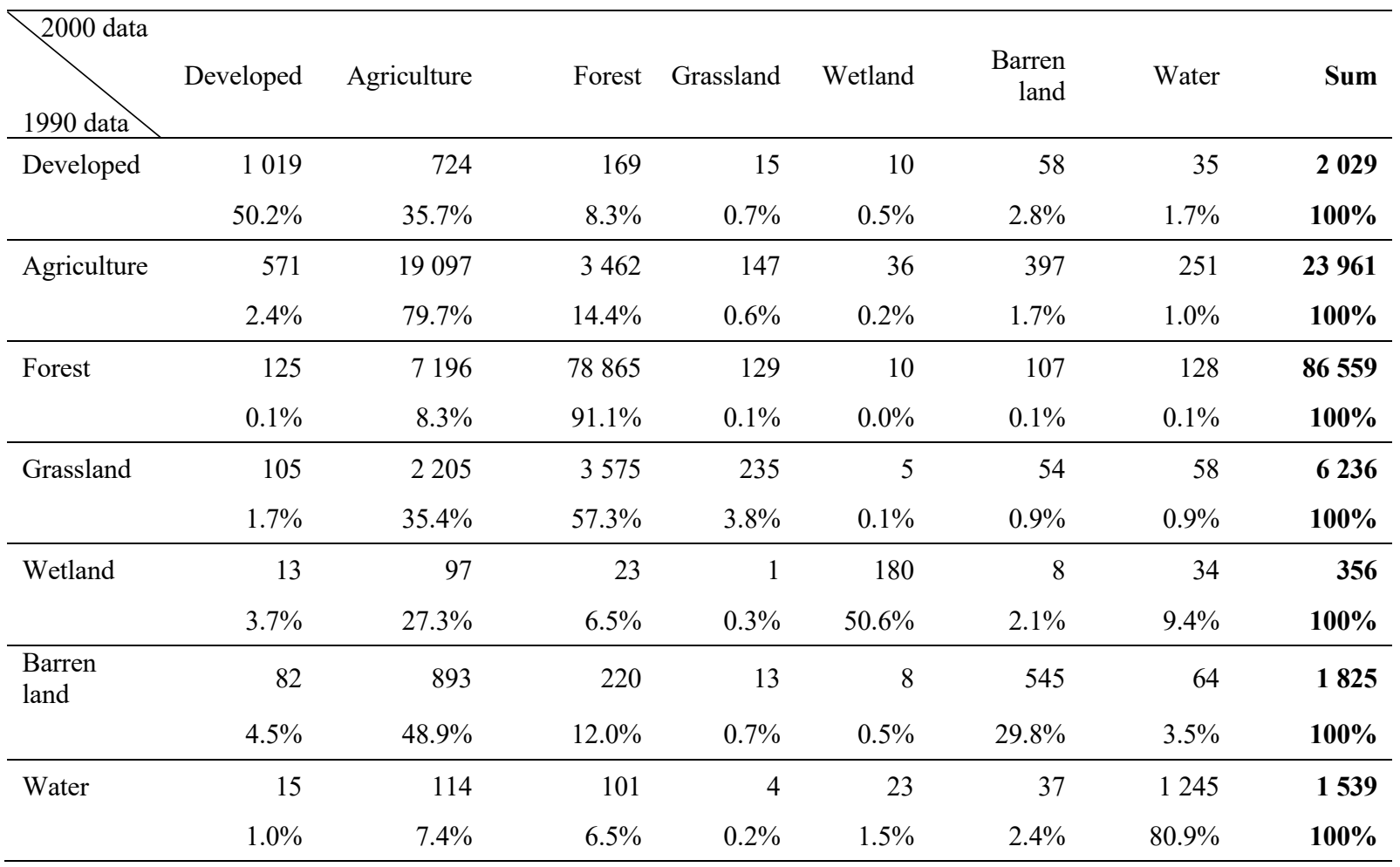

Fig. 3 illustrates the Grassland-to-Forest conversion in Yanggang-do during the 1990s2000s. In the 1990s, Grassland was quite widespread, located mostly between Agriculture and 246 Forest (Fig. 3 upper panel). In the 2000 data (Fig. 3 lower panel), much of the Grassland appears 247 as Forest or Agriculture. Between the 1980s and 1990s, many Forest pixels became Grassland or 248 Agriculture (not shown). Here an overarching phenomenon is the expansion of Agriculture. The 
249 Forest-to-Grassland conversion during the 1980s-1990s was probably due to efforts to obtain 250 firewood or to cultivate. During the 1990s-2000s, it seems Grassland changed to Agriculture or 251 vegetation continued to grow over Grassland, resulting in being classified as Forest.

252

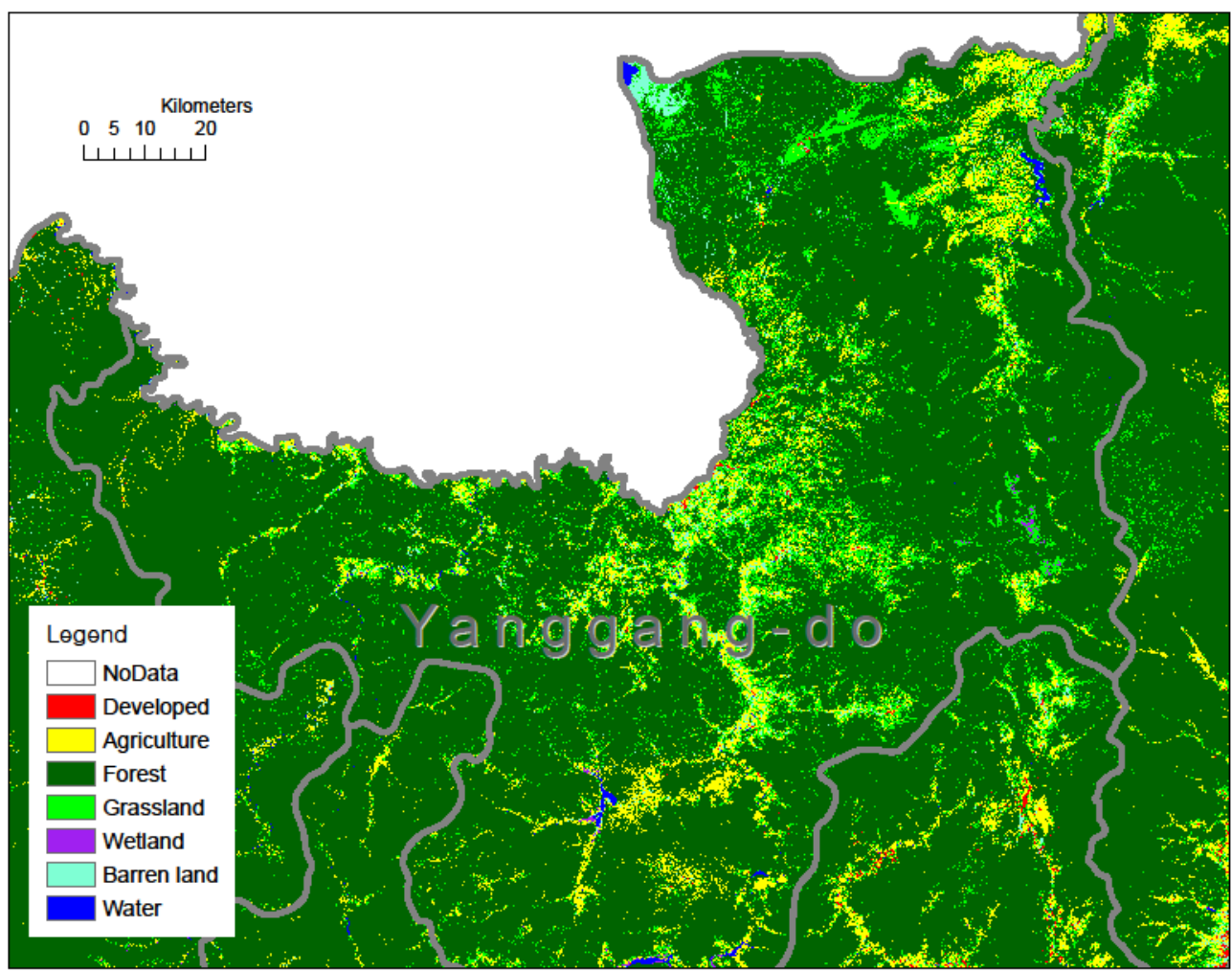




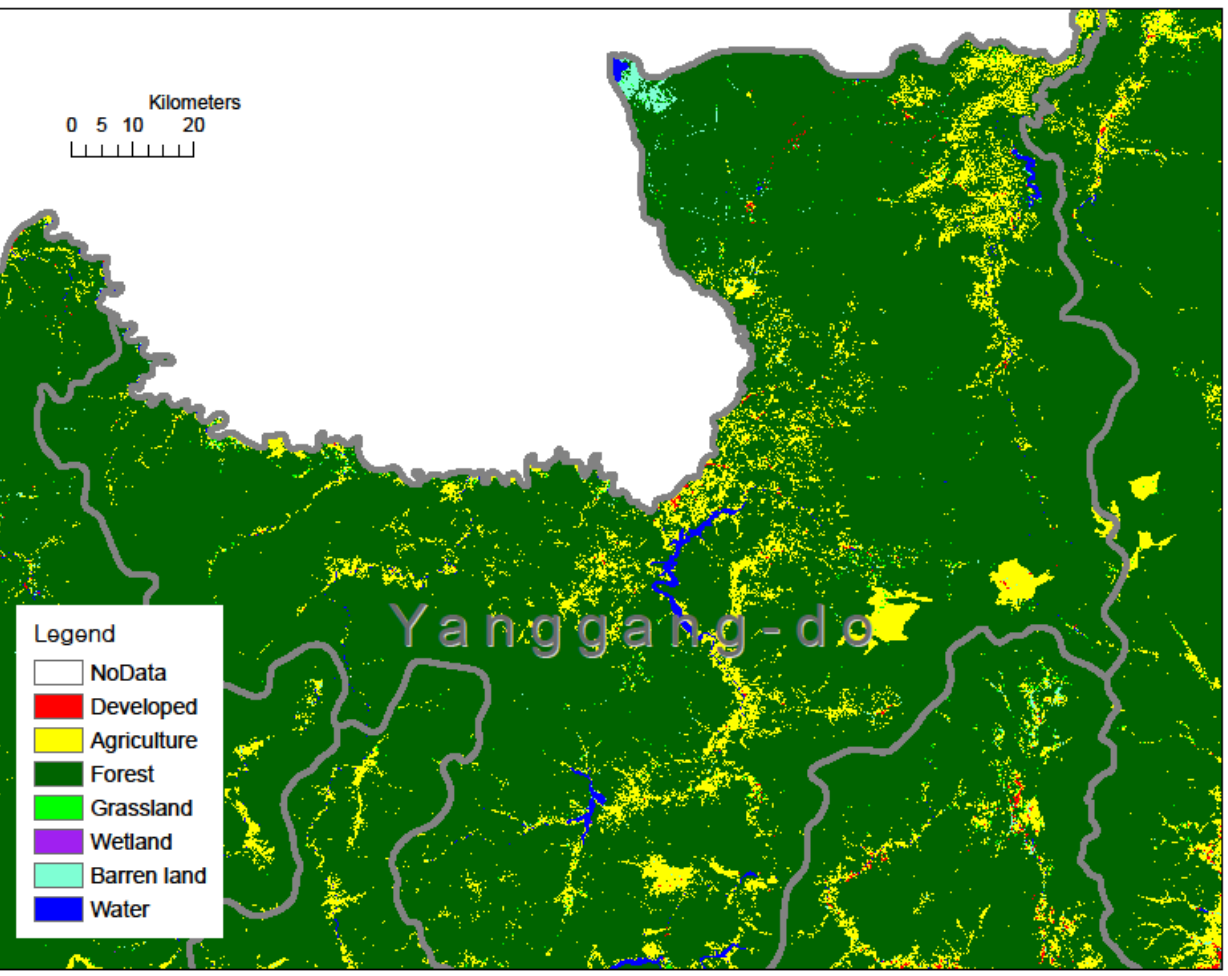

Fig. 3 Land cover over Yanggang-do from the 1990 data set (upper panel) and 2000 data set (lower panel) respectively

Table 6 shows land cover changes from Forest to other classes. Between the 1980s and 1990s, deforestation resulted mostly in Agriculture and Grassland. Of the Forest pixels that did not change during the $1980 \mathrm{~s}-1990 \mathrm{~s}, 5033 \mathrm{~km}^{2}$ of them changed to another land cover between the 1990s and the 2000s, almost exclusively to Agriculture. The conversion to Agriculture decreased in absolute terms, but it remained the most predominant conversion. On the other hand, the conversion to Grassland decreased dramatically. As found in Table 2, Grassland overall decreased substantially during the $1990 \mathrm{~s}-2000$ s whereas Agriculture increased by $27 \%$. The fact that about $60 \%$ of deforestation between the 1980s and 1990s resulted in Agriculture coincides with the massive food shortage during the 1990s. The large conversion from Forest to Grassland during the time is probably because trees were cut for firewood or conversion to agriculture is left incomplete. The Forest-to-Agriculture conversion continued during the 1990s-2000s but more slowly.

Table 6. Areal extent (in $\mathrm{km}^{2}$ ) of land cover changes from Forest to each of non-forest land cover classes. The second column shows the changes from Forest to non-forest cells during 
the 1980s-1990s. The third column shows the changes from Forest that did not change during the 1980s-1990s but changed during the 1990s-2000s.

\begin{tabular}{|l|r|r|}
\hline Change from Forest to & \multicolumn{1}{|r|}{ Time-90 } & \multicolumn{2}{|l|}{} \\
\hline Developed & 246 & 39 \\
\hline Agriculture & 6602 & 4780 \\
\hline Grassland & 3770 & 94 \\
\hline Wetland & 26 & 4 \\
\hline Barren land & 369 & 47 \\
\hline Water & 107 & 70 \\
\hline Total & $\mathbf{1 1 ~ 1 2 0}$ & $\mathbf{5 0 3 3}$ \\
\hline
\end{tabular}

Table 7 shows land cover changes that eventually resulted in Forest between the 1980s and 2000s. The overall size of forest cover as a result of land cover change is $10706 \mathrm{~km}^{2}$, approximately double the size of the overall forest cover decrease $\left(5446 \mathrm{~km}^{2}\right.$ from Table 2$)$ during the same period. Grassland, Forest, and Agriculture are the most important sources of conversion to Forest. Here conversion from Forest to Forest means 'Forest-something else-Forest' conversions. When Forest turned to something else in the 1990s, it mostly turned to Grassland and Agriculture. Conversion to Forest from other land covers is quite negligible.

Table 7. Land cover changes from non-forest to Forest $\left(\mathrm{km}^{2}\right)$ during 1980s-2000s. The change from Forest to Forest indicates that Forest became non-forest and became Forest again.

\begin{tabular}{|l|r|}
\hline To Forest from & 121 \\
\hline Developed & 3342 \\
\hline Agriculture & 4879 \\
\hline Forest & 2050 \\
\hline Grassland & 44 \\
\hline Wetland & \\
\hline
\end{tabular}




\begin{tabular}{|l|r|}
\hline Barren land & 155 \\
\hline Water & 115 \\
\hline Total & $\mathbf{1 0 ~ 7 0 6}$ \\
\hline
\end{tabular}

\section{Slope and elevation in deforested areas}

The maximum slope in the deforested areas during the 1990s-2000s was $17.3^{\circ}$, decreasing from $20.2^{\circ}$ during the $1980 \mathrm{~s}-1990 \mathrm{~s}$. On average, slope slightly decreased from $3.52^{\circ}$ to $3.24^{\circ}$, which is not statistically significant. The distribution of deforested areas by slope is portrayed in Fig. 4 as relative frequency. The distribution by slope is somewhat different between the two periods. During the latter decade, deforestation occurred in areas of slightly gentler slope than the earlier decade. It coincides with the large size of deforestation in western provinces where most of the plains are located.

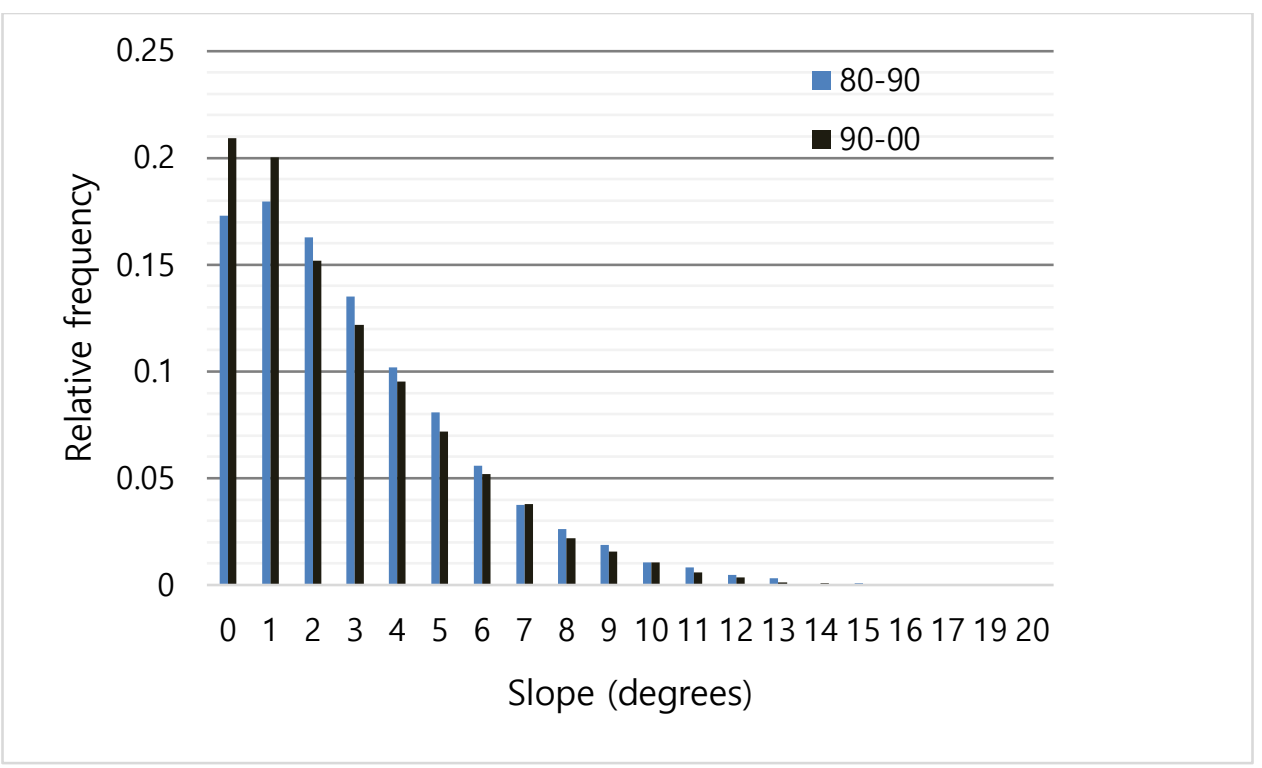

Fig. 4 Relative frequency of deforested areas by slope for the 1980s-1990s (left bars) and 1990s-2000s (right bars) periods

The maximum elevation of deforested areas slightly decreased from $2415 \mathrm{~m}$ for the 1980s-1990s to $2367 \mathrm{~m}$ for the 1990s-2000s. The mean elevation shows a somewhat large decrease, from $434 \mathrm{~m}$ for the 1980s-1990s to $354 \mathrm{~m}$ for the 1990s-2000s. The distribution of deforested areas by elevation is portrayed in Fig. 5 as cumulative probability. Unlike slope, 
elevation has far too many unique values, thus we decided to show as cumulative probability. The figure shows a noticeable difference for the elevation range of 200-1 $500 \mathrm{~m}$, reflecting the decrease in the mean elevations of deforested areas. For example, during the 1980s-1990s, about $80 \%$ of deforestation occurred under $800 \mathrm{~m}$, but during the $1990 \mathrm{~s}-2000 \mathrm{~s}$, the proportion was almost $90 \%$. The decrease in the mean elevation may mean that deforestation is more active at the lower elevation areas, which may be near urban areas or agricultural fields.

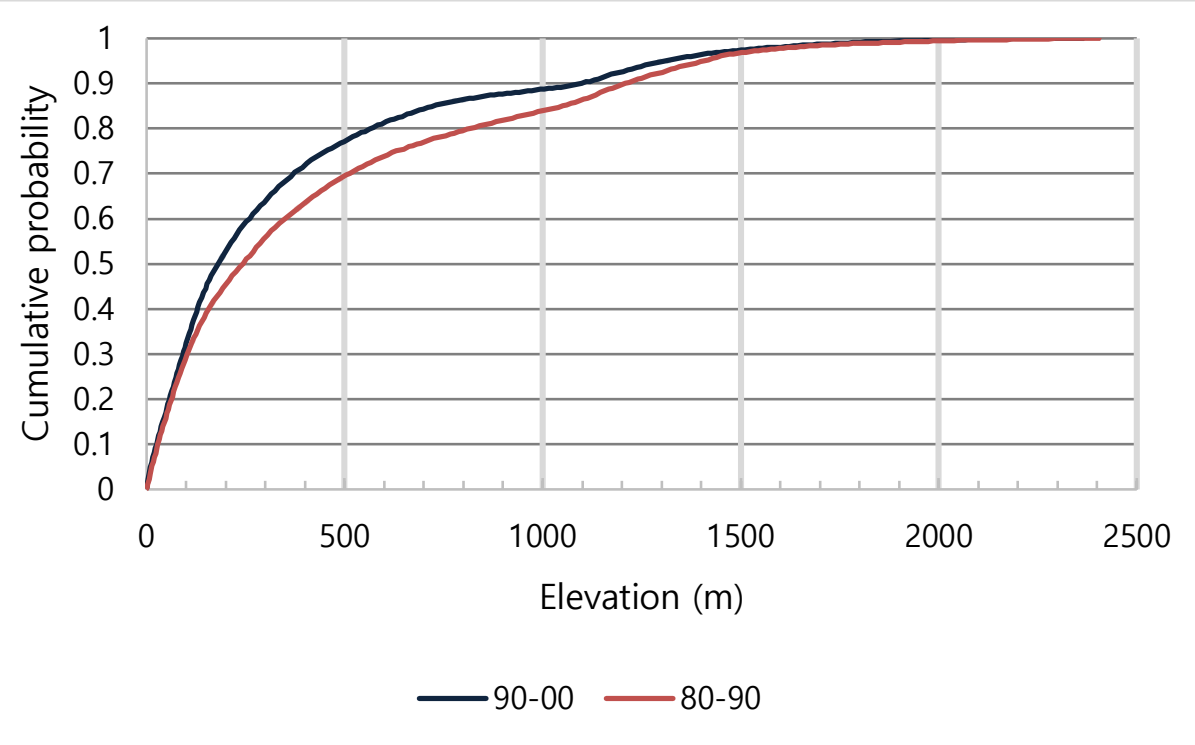

Fig. 5 Cumulative probability of deforested areas by elevation for the 1980s-1990s and the 1990s-2000s periods

CONCLUSIONS

Much of previous work in deforestation has mainly focused on issues related to tropical deforestation, and studies regarding North Korea have been sporadic. Especially, North Korea is a unique area of interest in relation to deforestation because of natural disasters, imprudent policies, and striving for self-reliance, requiring enormous demand for forest resources. This study attempted to examine the deforestation in terms of land cover change trajectory and its spatial characteristics between the 1980s and the 2000s using three land cover data sets representing each decade. The results are summarised as follows: (1) net forest loss in North Korea slowed since the 1990s, whereas land cover changes were active; (2) as a result of deforestation, forest land cover became mostly agricultural and grass lands; (3) expansion of 
326 agricultural land cover continued during the time; and (4) deforestation appears to have occurred 327 more frequently in areas of slightly lower elevation and gentler slope during the 1990s-2000s than 328 the earlier decade. The key contribution of the study is that it has demonstrated which land cover class became which at the pixel level, complementing existing studies that examined overall forest stock in North Korea. The finding that deforestation mostly resulted in Agriculture and Grassland corroborates the existing explanation for deforestation, food and fuel shortage.

332

333

Acknowledgment

334 This work was supported by a grant from Kyung Hee University in 2015. 
Debolini M, Schoorl JM, Temme A, Galli M, Bonari E. 2013. Changes in agricultural land use affecting future soil redistribution patterns: a case study in southern Tuscany (Italy). Land Degrad. Dev. 26:574-586. DOI: 10.1002/ldr.2217

Engler R, Teplyakov V, Adams JM. 2014. An Assessment of Forest Cover Trends in South and North Korea, From 1980 to 2010. Environ. Manage. 53:194-201. DOI: 10.1007/s00267-0130201-y

Feng H, Liu Y. 2014. Trajectory based detection of forest-change impacts on surface soil moisture at a basin scale [Poyang Lake Basin, China]. J. Hydrol 514: 337-346.

Findell KL, Shevliakova E, Milly PCD, and Stouffer RJ, 2007. Modeled Impact of Anthropogenic Land Cover Change on Climate. J. Climate, 20: 3621-3634.

Food and Agriculture Organization of the United Nations (FAO). 2012. State of the World's Forests. Rome, Italy. ISBN 978-92-5-107292-9

Food and Agriculture Organization of the United Nations (FAO). 2010. Global Forest Resources Assessment 2010. Rome, Italy. ISBN 978-92-5-106654-6

Geist HJ, Lambin EF. 2002. Proximate Causes and Underlying Driving Forces of Tropical Deforestation. Bioscience 52(2): 143-150.

International Union of Forest Research Organizations (IUFRO). 2007. Keep Asia Green Volume 2: Northeast Asia, Online document at http://www.iufro.org/download/file/7729/153/ws20-ii_pdf/ (Accessed on 2014. 1. 6.).

Kang S, Choi W. 2014. Forest cover changes in North Korea since the 1980s. Reg. Environ.

Change. 14: 347-354, DOI: 10.1007/s10113-013-0497-4

Kim C, Chi K. 1998. Flood Damage Mapping in North Korea Using Multi-Sensor Data. Proceedings $19^{\text {th }}$ Asian Conference of Remote Sensing.

Kim JH, Park SH. 1995. Foreign trade of North Korea in 1994. North Korea's Current Report 952. Korea Trade-Investment Promotion Agency.

Kim YC. 2009. North Korea, where to go?. Planet Media. Seoul. Korea. 427p

Lee KS, Kim JH. 2000. Change Analysis of Forest Area and Canopy Conditions in Kaesung, North Korea Using Landsat, SPOT, and KOMPSAT Data. Journal of the Korean Society of 
Remote Sensing 16(4): 327-338.

Lee YH. 2008. Status and Prospects of the North Korean Economy: the swamp of poverty Big Push?. International Workshops on Current and Future Prospects of the North Korean Economy. Institute for Far Eastern Asia \& Kyungnam University.

Ministry of Environment (MoE). 2013. Guideline on Land Cover Mapping. Ministry of Environment Directive No. 1036 issued on 2013. 4. 19. Downloadable at http://www.law.go.kr/flDownload.do?flSeq=14256939 (in Korean; last accessed 2016. 1. 22)

Ministry of Environment (MoE). 2016a. Environmental Spatial Information Service. Online document at http://egis.me.go.kr/ba/grdCoverIntroPage.do?mode=3 $\quad$ (last accessed 2016. 1. 22)

Ministry of Environment (MoE). 2016b. Environmental Spatial Information Service. Online document at http://egis.me.go.kr/bc/largeGrdCover_2000.do (last accessed 2016. 1. 22)

Myeong SJ, Hong HJ. 2009. Developing Flood Vulnerability Map for North Korea. Korea Environment Institute.

NASA. 2012. ASTER Global Digital Elevation Map Announcement. Online document at http://asterweb.jpl.nasa.gov/gdem.asp (Accessed on 2014. 1. 6)

Parton WJ, Gutmann MP, Williams SA, Easter M, Ojima D. 2005. Ecological impact of historical land-use patterns in the Great Plains: A methodological assessment. Ecol. Appl. $15: 1915-1928$

Sajikumar N, Remya RS. 2015. Impact of land cover and land use change on runoff characteristics. J. Environ. Manage. 161:460-468.

Stone R, 2012, Seeking Cures for North Korea's Environmental Ills, Science 335: 23 March 2012 United Nations Environment Programme (UNEP). 2003. DPR Korea: State of the Environment. Online document at http://www.unep.org/PDF/DPRK_SOE_Report.pdf (Accessed on 2014. 1.6).

United Nations Framework Convention on Climate Change (UNFCCC). 2007. Investment and Financial Flows to Address Climate Change.

Vagen T-G. 2006. Remote sensing of complex land use change trajectories - a case study from the highlands of Madagascar. Agriculture, Ecosystems and Environment 115: 219-228.

Wang D, Gong J, Chen L, Zhang L, Song Y, Yue Y. 2013. Comparative analysis of land use/cover change trajectories and their driving forces in two small watersheds in the western Loess 
Plateau of China. Int. J. Appl. Earth Obs. Geoinf. 21: 241-252. DOI: 10.1016/j.jag.2012.08.009

399

Zhao S, Peng C, Jiang H, Tain D, Lei X, Zhou X. 2006. Land Use Change in Asia and the 400 Ecological Consequences. Ecol. Res. 21(6): 890-896.

401 